\title{
A lowered 265 proteasome activity correlates with mantle lymphoma cell lines resistance to genotoxic stress
}

Khaoula Ben Younes ${ }^{1,2}$, Simon Body ${ }^{1}$, Élodie Costé ${ }^{1}$, Pierre-Julien Viailly ${ }^{1,3}$, Hadjer Miloudi ${ }^{1}$, Clémence Coudre ${ }^{1}$ Fabrice Jardin ${ }^{1,3}$, Fatma Ben Aissa-Fennira ${ }^{2}$ and Brigitte Sola $a^{1,4^{*}}$ (D)

\begin{abstract}
Background: Mantle cell lymphoma $(\mathrm{MCL})$ is a B-cell hemopathy characterized by the $t(11 ; 14)$ translocation and the aberrant overexpression of cyclin D1. This results in an unrestrained cell proliferation. Other genetic alterations are common in MCL cells such as SOX11 expression, mutations of ATM and/or TP53 genes, activation of the NF-KB signaling pathway and NOTCH receptors. These alterations lead to the deregulation of the apoptotic machinery and resistance to drugs. We observed that among a panel of $M C L$ cell lines, REC1 cells were resistant towards genotoxic stress. We studied the molecular basis of this resistance.
\end{abstract}

Methods: We analyzed the cell response regarding apoptosis, senescence, cell cycle arrest, DNA damage response and finally the 265 proteasome activity following a genotoxic treatment that causes double strand DNA breaks.

Results: MCL cell lines displayed various sensitivity/resistance towards genotoxic stress and, in particular, REC1 cells did not enter apoptosis or senescence after an etoposide treatment. Moreover, the G2/M cell cycle checkpoint was deficient in REC1 cells. We observed that three main actors of apoptosis, senescence and cell cycle regulation (cyclin D1, MCL1 and CDC25A) failed to be degraded by the proteasome machinery in REC1 cells. We ruled out a default of the $\beta \operatorname{TrCP} E 3-$ ubiquitine ligase but detected a lowered 26S proteasome activity in REC1 cells compared to other cell lines.

Conclusion: The resistance of MCL cells to genotoxic stress correlates with a low 265 proteasome activity. This could represent a relevant biomarker for a subtype of $\mathrm{MCL}$ patients with a poor response to therapies and a high risk of relapse.

Keywords: B-cell lymphoma, Apoptosis, Cell cycle, Senescence, Resistance/sensitivity, Double-strand break, DNA repair, Ubiquitin ligase, 265 proteasome, PSMB6

\section{Background}

Mantle cell lymphoma (MCL) is an aggressive lymphoid malignancy derived from mature B cells, characterized by a rapid clinical evolution and a poor response to current therapies [1]. The first oncogenic hit for tumor development is the translocation $\mathrm{t}(11 ; 14)(\mathrm{q} 13 ; \mathrm{q} 32)$ which juxtaposes activating sequences from the $I G H$ gene promoter upstream of the CCND1 gene. This translocation leads to the constant expression of cyclin D1 protein and in turn, abnormalities of cell cycle, and compromises the G1-S checkpoint [1]. This initial oncogenic

\footnotetext{
* Correspondence: brigitte.sola@unicaen.fr

${ }^{1}$ Normandie Univ, INSERM UMR 1245, UNIROUEN, UNICAEN, Caen, France

${ }^{4}$ MICAH, UFR Santé, CHU Côte de Nacre, 14032 Caen Cedex, France

Full list of author information is available at the end of the article
}

event is followed by various chromosomal alterations targeting DNA damage response (DDR), survival pathways, $\mathrm{NOTCH}$ and NF- $\mathrm{KB}$ pathways, and chromatin modification machinery [2] as well as reprograming metabolism [3].

ATM (Ataxia telangectasia mutant) and ATR (ATM and Rad3-related) act as apical kinases and key regulators of DDR. Following double-strand DNA breaks (DSBs), ATM/ATR phosphorylate downstream effectors including checkpoint kinases (CHK1/CHK2), DNA repairing factors and transcriptional regulators such as p53 [4]. Next, depending on the cellular context, cells initiate cell cycle arrest, DNA repair through two main mechanisms: homologous recombination (HR) or nonhomologous end joining (NHEJ), and/or apoptosis. ATM 
alterations are very common in MCL patients, mutations and deletions occurring in up to half of cases [5]. Genetic alterations of TP53 are also very common (30\% of cases) and concurrent alterations of ATM and TP53 are found in almost $10 \%$ of patients [6]. Defaults in responding intracellular and extracellular genotoxic stresses could explain why MCL is the B-cell malignancy with the highest degree of genomic instability [7].

Abnormalities of the ubiquitin-proteasome pathway are also recognized in MCL cells. They could account for defaults in the DDR and resistance towards genotoxic drugs that are used in clinics such as cyclophosphamide, doxorubicin and chlorambucil [8]. For example, MCL cells show frequent deletion within the FBXO25 gene located at 8p23.3 [9]. FBXO25 encodes a F-box containing protein, part of the Skp1/Cullin/F-box containing protein or $\mathrm{SCF}^{\mathrm{FBXO} 25}$ complex that targets the prosurvival HAX1 mitochondrial protein. The monoallelic loss of FBXO25 and thus, the disruption of the PRKCD (a protein kinase C)/FBXO25/HAX1 axis promotes survival of MCL cells. A high percentage of MCL tumors (20\%) have mutations within the UBR5 gene [10]. UBR5 encodes an E3 ubiquitin ligase that targets KATNA1 (katanin p60), TOPBP1 (DNA topoisomease 2-binding protein 1) and PAIP2 (polyadenylatebinding protein-interacting protein 2) proteins whose functions are not fully known. The human double minute(HDM)-2 E3 ubiquitin ligase plays a key role in p53 turnover. The gene is located within the $12 \mathrm{q} 13$ locus which is amplified in MCL [11]. This accounts for elevated HDM2 expression and prevention of both p53 transcriptional activity and degradation. Thus, the response of MCL cells to DNA damaging agents is impaired through various mechanisms.

Studying a set of MCL cell lines, we noticed that REC1 cells were particularly resistant to genotoxic stresses. Looking for cellular mechanisms that could sustain this resistance, we observed that the ubiquitin/proteasome degradation pathway was inefficient. We ruled out a default of $\beta$-transducin repeat containing protein $(\beta \operatorname{TrCP})$, the E3 ubiquitin ligase of the $\mathrm{SCF}^{\beta \mathrm{TrCP}}$ complex which was a good candidate. We further used fluorescent probes to study specifically the $26 \mathrm{~S}$ proteasome activity and observed that this activity was specifically down-regulated in REC1 cells compared to other MCL cell lines.

\section{Methods}

\section{Cell cultures, treatments and cell proliferation determination}

MCL cell lines were provided by Gaël Roué (IDIBAPS, Barcelona, Spain) except Granta519 cells which were purchased from DSMZ (ACC-342). MCL cell lines were maintained in culture as described [12]. Cell authentication was done by STR profiling (IdentiCell, Aarhus, Denmark).
Cell proliferation was analyzed using the CellTiter $96^{\circ}$ AQueous One Solution Cell Proliferation assay (Promega, Charbonnières, France) according to the supplier. MCL cells were treated with vehicle (0.01\% DMSO) or 1-40 $\mu \mathrm{g}$ / $\mathrm{ml}$ etoposide (Sigma-Aldrich, St Louis, MO) for 24-72 h depending on the experiment. For co-treatment with MG132, the cells were incubated with $5 \mu \mathrm{M}$ MG132 (Sigma-Aldrich) together with $4 \mu \mathrm{g} / \mathrm{ml}$ etoposide for $24 \mathrm{~h}$.

\section{Quantification of apoptotic and senescent cells, cell cycle analysis}

MCL cells exposed to vehicle or etoposide were stained with an Apo 2.7 PE-conjugated antibody (Ab, Beckman Coulter, Villepinte, France). The APO2.7-stained cells were analyzed by flow cytometry (Gallios, Beckman Coulter) and data were processed with the Kaluza software (Beckman Coulter). At least, $2 \times 10^{4}$ cells were analyzed for each culture condition, for each experiment.

For cell cycle experiments, the cells were washed with PBS and fixed in $70 \%$ ethanol/PBS at $-20{ }^{\circ} \mathrm{C}$ for $30 \mathrm{~min}$. After washing, the cells were then incubated with PBS containing $10 \mathrm{mg} / \mathrm{ml}$ of propidium iodide (PI) and $100 \mathrm{mg} / \mathrm{ml}$ of RNAse A. At least, $2 \times 10^{4}$ cells were analyzed by flow cytometry for each experimental condition.

To assess the presence of senescent cells after etoposide treatment $(4 \mu \mathrm{g} / \mathrm{ml}$ for $24 \mathrm{~h})$, we used a cytometrybased assay after staining of living cells with 5dodecanoylaminofluorescein di- $\beta$-D-galactopyranoside $\left(C_{12}\right.$ FDG) as described previously [13]. A shift of the mean fluorescence intensity (MFI) is representative of an enrichment of senescent cells in the whole population.

\section{Indirect immunofluorescence and confocal fluorescence microscopy analysis}

Cells $\left(10^{5}\right.$ cells per spot) were cytospun on Superfrost glass slides, at $500 \mathrm{x}$ g for $3 \mathrm{~min}$, then fixed in $4 \%$ paraformaldehyde (PFA) for $15 \mathrm{~min}$, and permeabilized by incubation with $0.5 \%$ Triton-X100 $(\mathrm{v} / \mathrm{v})$ for $5 \mathrm{~min}$. The slides were then incubated with $3 \%$ BSA in PBS for $30 \mathrm{~min}$ at room temperature and, next with Abs anti- $\gamma \mathrm{H} 2 \mathrm{AX}$ (pS139, final dilution 1/2000) (GTX61796 from GeneTex Inc., Irvine, CA) or anti-cyclin D1 (sc-718, Santa Cruz Tech., final dilution 1/50) for overnight in the dark at $4^{\circ}$ C. Goat anti-rabbit IgG $(\mathrm{H}+\mathrm{L})$ polyclonal Alexa Fluor ${ }^{\circ}$ 546 (Life Technologies) served as secondary Ab. Following staining steps, cells were mounted with VECTASHIELD ${ }^{\circ}$ with DAPI (Vector Lab.). The slides were analyzed with the Fluoview FV 1000 confocal microscope and Fluoview Viewer software (Olympus, Rungis, France).

\section{Western blotting}

Whole cell lysates and western blotting were prepared as previously described [12]. Using the Cell Fractionation Kit (\#9038, Cell Signaling Tech.), we separated cells into 
cytoplasmic (c), membrane/organelle (m), and nuclear/ cytoskeletal (n) fractions and prepared the corresponding protein extracts according to the manufacturer's instructions. We used primary Abs against $\beta$-actin (sc47,778 , final dilution 1/1000), cyclin D1 (sc-718, final dilution 1/400), cyclin D2 (sc-593, final dilution 1/200), p53 (sc-126, final dilution 1/400), p16 ${ }^{\mathrm{INK} 4 \mathrm{~A}}$ (sc-468, final dilution 1/100), and $\mathrm{p} 21^{\mathrm{CIP} 1}$ (sc-397, final dilution $1 /$ 400) from Santa Cruz Biotech. (Santa Cruz, CA). We purchased Abs against MCL1 (\#4572, final dilution 1/ 500), p-T256-cyclin D1 (\#3300, final dilution 1/1000), CHK2 (\#6334, final dilution 1/200), p-T68-CHK2 (\#2197, final dilution 1/1000), p-S15-p53 (\#9286, final dilution 1/1000), $\beta \operatorname{TrCP1}((\# 4394$, final dilution 1/1000) from Cell Signaling Tech. (Danvers, MA). An Ab against BCL2 (clone 124, M0887, final dilution 1/200) was purchased from Dako (Glostrup, Denmark); an Ab against $\gamma \mathrm{H} 2 \mathrm{AX}$ (GTX61796, final dilution 1/1000) from Genetex (Irvine, CA); an Ab against GAPDH (clone 6C5, final dilution 1/2000) from Ambion (Thermo Fischer Scientific, Waltham, MA). We used ImmunoPure goat anti-rabbit or rabbit anti-mouse IgG peroxidase-conjugated as secondary Abs (Pierce, Thermo Fisher Scientific). For densitometric analyses, images were captured with a ChemiDoc $^{\text {TM }} \mathrm{XRS}+$ molecular imager and analyzed using Image Lab $^{\text {tw }}$ software (Bio-Rad). The background of each image was subtracted from the bands of interest, then the densities of each protein of interest were normalized against the density of control housekeeping proteins.

\section{Proteasome function assays}

Our procedure was adapted from Vlashi et al. [14]. Cells were washed with PBS, pelleted and lysed in a homogenization buffer (25 mM Tris $\mathrm{pH} 7.5,100 \mathrm{mM}$ $\mathrm{NaCl}, 5 \mathrm{mM}$ ATP, $0.2 \%$ (vol/vol) NP-40 and 20\% glycerol). Cell debris were removed by centrifugation at $4{ }^{\circ} \mathrm{C}$. Protein concentration in the resulting crude cellular extracts was determined. To measure $26 \mathrm{~S}$ proteasome activity, $100 \mu \mathrm{g}$ of protein of each sample were diluted with buffer I (50 mM Tris $\mathrm{pH} 7.4,2 \mathrm{mM}$ dithiothreitol, $5 \mathrm{mM} \mathrm{MgCl}_{2}$, $2 \mathrm{mM}$ ATP) to a final volume of $1 \mathrm{ml}$ and assayed in triplicate. The fluorogenic proteasome substrates Suc-LLVYAMC (chymotryptic substrate; Enzo Life Sciences, Villeurbanne, France), Z-ARR-AMC (tryptic substrate; Calbiochem, Molsheim, France), and Z-LLE-AMC (caspase-like substrate; Enzo Life Sci.) were dissolved in DMSO and added to a final concentration of $80 \mu \mathrm{M}$. Proteolytic activities were continuously monitored for 120 min by measuring the release of the fluorescent group, 7-amido-4methylcoumarin (AMC), with the use of a fluorescence plate reader (VICTOR X4 multilabel plate reader, Perkin Elmer) at $37{ }^{\circ} \mathrm{C}$, at excitation and emission wavelengths of 380 and $460 \mathrm{~nm}$, respectively. For analyzing the effects of proteasome/protease inhibitors on proteasome activities, cells were treated for $4 \mathrm{~h}$ with MG-132 (500 nM), bortezomib $(5 \mathrm{nM})$ or leupeptin $(20 \mu \mathrm{M})$ before the purification of whole cell extracts.

RNA extraction and real-time polymerase chain reaction Total RNAs were extracted using RNAeasy ${ }^{\circ}$ Mini kit (Qiagen, Venlo, The Netherlands) according to the manufacturer's instructions and quantified using a Smartspec ${ }^{\text {TM }}$ 3000 spectrometer (Bio-Rad, Hercules, CA) from cultured MCL cells. cDNAs were synthesized using $2 \mu \mathrm{g}$ of RNA and $\mathrm{M}-\mathrm{MuLV}$-reverse transcriptase as recommended by the supplier (Invitrogen, Thermo Fisher Scientific). SYBR Green real-time polymerase chain reaction (RT-PCR, Applied Biosystems, Thermo Fisher Scientific) was performed on cDNAs with primers for $B T R C$ and $F B X W 11$ previously described [15], using a StepOnePlus real-time PCR System (Applied Biosystems). Data were analyzed with the Step One software V2.2.2 (Applied Biosystems). Gene expression was determined by real-time RT-PCR and quantified using $G A P D H$ expression as internal standard. Relative gene expression was evaluated by the $2^{-\Delta \Delta \mathrm{Ct}}$ method.

\section{Statistical analysis}

The Student's $t$-test was used to determine the significance of differences between two experimental groups. Data were analyzed by two-sided tests, with $p<0.05$ (*) considered to be significant.

\section{Results}

MCL cell lines demonstrate differences in sensitivity to genotoxic agents

Etoposide, an inhibitor of topoisomerase 2 (Top 2), induces DSBs and triggers apoptosis. The response of five MCL cell lines (Granta519, Mino, REC1, NCEB1 and JeKo1) to etoposide was determined by a MTS cell proliferation assay. Cell lines were either exposed to vehicle or $1 \mu \mathrm{g} / \mathrm{ml}$ etoposide for $24-72 \mathrm{~h}$ or increasing concentrations of etoposide $(1-40 \mu \mathrm{g} / \mathrm{ml})$ for $24 \mathrm{~h}$. Etoposide-treatment led to a dose- and time-dependent inhibition of proliferation (Fig. 1A). However, MCL cells displayed various sensitivities and in particular, REC1 and NCEB1 were more resistant than JEKO1, Mino and Granta519 cells ( $p$-value $=0.0134$ with the $t$-test). Using the PRISM 6 software, we analyzed the MTS data and calculated the $\mathrm{IC}_{50}$ and the area under the curve (AUC) for each cell line, for each treatment condition (Additional file 1: Figure S1). The gradient of sensitivity/resistance among the cell lines was confirmed (Additional file 2: Tables S1 and S2). We next selected three cell lines: REC1 (etoposide-resistant), NCEB1 (intermediate response) and JeKo1 (etoposide-sensitive) for studying the molecular basis of these responses. 

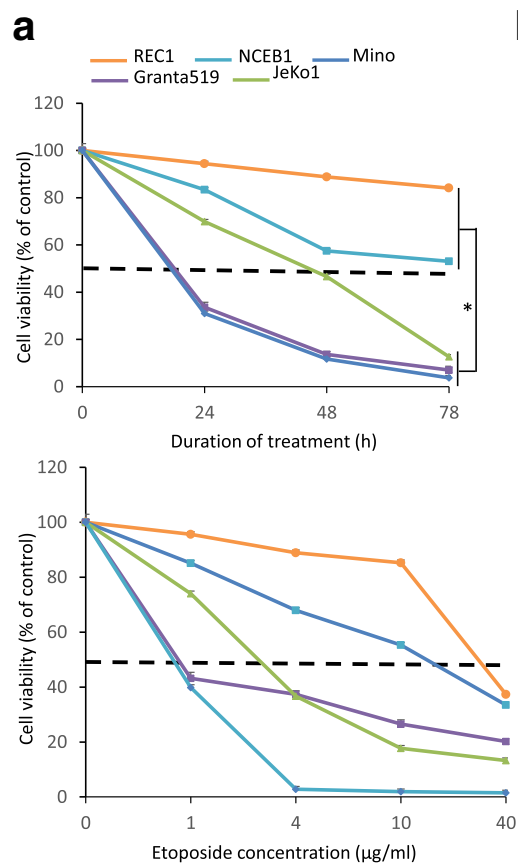

b

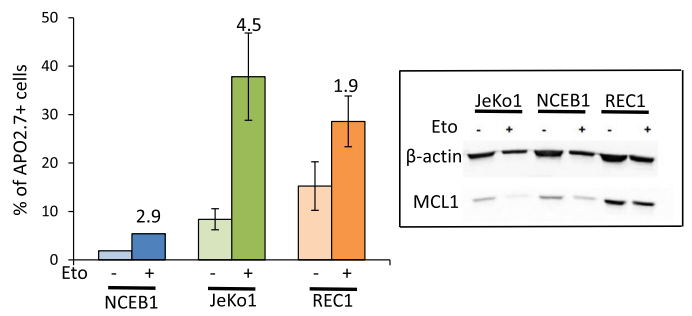

C

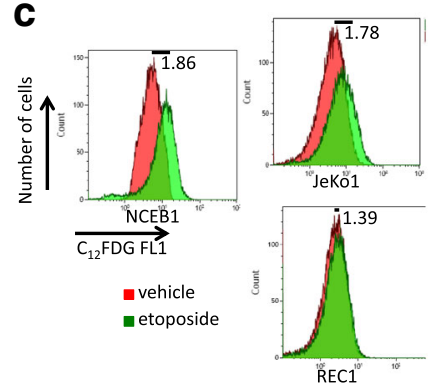

Fig. $1 \mathrm{MCL}$ cell lines are either sensitive or resistant to etoposide treatment. a. Exponentially growing Granta519, JeKo1, MINO, NCEB1 and REC1 cells were seeded at $5 \times 10^{4}$ cells/well in 96-well plates and treated with vehicle, as a control, or $1 \mu \mathrm{g} / \mathrm{ml}$ etoposide for $24-72 \mathrm{~h}$ (upper panel) or with various concentrations of etoposide (1-40 $\mathrm{\mu g} / \mathrm{ml})$ for $24 \mathrm{~h}$ (lower panel). The cell proliferation was analyzed using an MTS assay and calculated as the ratio of absorbance of etoposide-treated cells vs. vehicle-treated cells for each time point and concentration. The absorbance values at $492 \mathrm{~nm}$ were corrected by subtracting the average absorbance from the control wells containing "no cells". The experiment was performed twice, each culture condition was done in triplicate. The comparison of sensitive (Granta519, MINO and JeKo1) and resistant (REC1, NCEB1) using the t-test was significant. ${ }^{*}, p<0.05$. b. Left part, MCL cells were treated with vehicle or $4 \mu \mathrm{g} / \mathrm{ml}$ etoposide for $24 \mathrm{~h}$, stained with an anti-APO2.7 PE-conjugated Ab and analyzed by flow cytometry. The experiment was performed twice (for NCEB1) or three times; at least 10,000 events were gated for each culture condition. Means \pm SD of $\%$ of APO2.7+ cells are indicated in the histogram as well as the fold induction (FI) calculated as the ratio of \% APO2.7+ in etoposide- vs. vehicle-treated cultures. Right part, whole cell proteins were extracted, $40 \mu \mathrm{g}$ of proteins were loaded on gels, separated by SDS-PAGE, blotted onto nitrocellulose membranes, incubated with Abs anti-MCL1, anti-BCL2 or anti- $\beta$-actin (as a loading control). c. MCL cells were treated with $4 \mathrm{\mu g} / \mathrm{ml}$ etoposide for $24 \mathrm{~h}$ or vehicle, as a control, then stained with $\mathrm{C}_{12}$ FDG and analyzed by flow cytometry. At least 10,000 events were gated for each culture condition. The ratio mean of fluorescence intensity of vehicle vs. etoposide-treated cells is indicated on the figure

\section{REC1 cells do not enter apoptosis or senescence after genotoxic stress}

We analyzed the effects of etoposide on the induction of cell apoptosis. MCL cells were treated with $4 \mu \mathrm{g} / \mathrm{ml}$ etoposide for $24 \mathrm{~h}$ and apoptosis assayed after APO2.7 staining and flow cytometry analysis. Although JeKo1 cells underwent apoptosis (fold induction $(\mathrm{FI})=4.5$ ), NCEB1 and REC1 cells did not show a similar magnitude (FI = 2.9 and 1.9, respectively) (Fig. 1B). In agreement with this observation, the level of MCL1 was gradually downregulated in MCL cells. The extent of downregulation was estimated by densitometry imaging and correlated with the amplitude of apoptototic response (Additional file 2: Table S3). MCL1 protein degradation is mandatory for MCL cell death [16]. In turn, the resistance of REC1 to genotoxic stress could be due to a defect of MCL1 degradation.

Following DNA damage, DDR is coordinated by ATM and ATR that phosphorylate multiple downstream targets and lead finally to cell cycle arrest, DNA repair or apoptosis [17]. DNA damage could also trigger an irreversible arrest of cell proliferation known as senescence [18]. We used $\mathrm{C}_{12}$ FDG, a membrane-permeable molecule that stains senescent cells [13] for analyzing cell response after etoposide treatment. The number of $\mathrm{C}_{12}$ FDG-stained NCEB1 and JeKo1 but not REC1 cells increased after treatment (Fig. 1C). To induce the long-term cell cycle arrest that accompanies senescence, two cell cycle inhibitors need to be up-regulated, p21 ${ }^{\mathrm{CIP} 1}$ and $\mathrm{p} 16^{\mathrm{INK} 4 \mathrm{~A}}$. The level of both proteins was enhanced in etoposide-treated NCEB1 but not in REC1 cells (data not shown). These results showed that REC1 cells escaped both senescence and apoptosis following genotoxic stress.

\section{Etoposide activates DDR in MCL cells}

The resistance of REC1 cells to genotoxic stress could be due to alterations of DDR pathway. DSBs activate ATM/ATR kinases which leads to the phosphorylation of histone $\mathrm{H} 2 \mathrm{AX}$ on Ser139 residues and generates $\gamma \mathrm{H} 2 \mathrm{AX}$ [19]. ATM/ATR apical kinases activate also DNA damage checkpoints to arrest cell cycle progression for repairing DNA [20]. We first evaluated the extent of DSBs generated following genotoxic 
stress. Immunocytofluorescence (ICF) analyses were performed after a 24-h treatment with $4 \mu \mathrm{g} / \mathrm{ml}$ etoposide. DSBs were absent in vehicle-treated NCEB1 and JeKo1 cells, and induced by etoposide-treatment (Fig. 2a). In contrast, vehicletreated as well as untreated REC1 cells presented $\gamma \mathrm{H} 2 \mathrm{AX}$ foci representative of ongoing DNA damage (Fig. 2a, b and Fig. 3e). We next examined the kinetics of $\gamma \mathrm{H} 2 \mathrm{AX}$ generation in cells treated with $4 \mu \mathrm{g} / \mathrm{ml}$ etoposide by western blotting. $\gamma \mathrm{H} 2 \mathrm{AX}$ foci present in vehicle-treated REC1 cells progressed not much after etoposide treatment (Fig. 2b). In NCEB1 and JeKo1 cells, the level of $\gamma \mathrm{H} 2 \mathrm{AX}$ protein increased until $6 \mathrm{~h}$ then decreased indicating that DSBs were indeed repaired (Fig. 2b). This result showed that HR and/or NHEJ mechanisms of DNA repair were fully functional in NCEB1 and
JeKo1 cells. However, according to Williamson et al. [21], NCEB1 and JeKo1 cells are TP53-mutated (Additional file 2: Table S4 and Fig. 2c) and in turn, unable to repair all DNA breaks driving cells to death. Interestingly, apoptosis induced in these responsive cells is p53-independent. DSBs were also able to activate $\mathrm{CHK} 2$ as observed by the phosphorylated state of the protein in REC1 cells (Fig. 2c). In that case, as shown both by the presence of $\gamma \mathrm{H} 2 \mathrm{AX}$ foci before any genotoxic treatment and after (Fig. 2a, b and Fig. 3e), and the phosphorylation of CHK2 (Fig. 2d), no DNA repair occurred. We concluded that DDR was activated in MCL cell lines including REC1 cells. However, DNA repair mechanisms were inefficient or incomplete in REC1 cells.

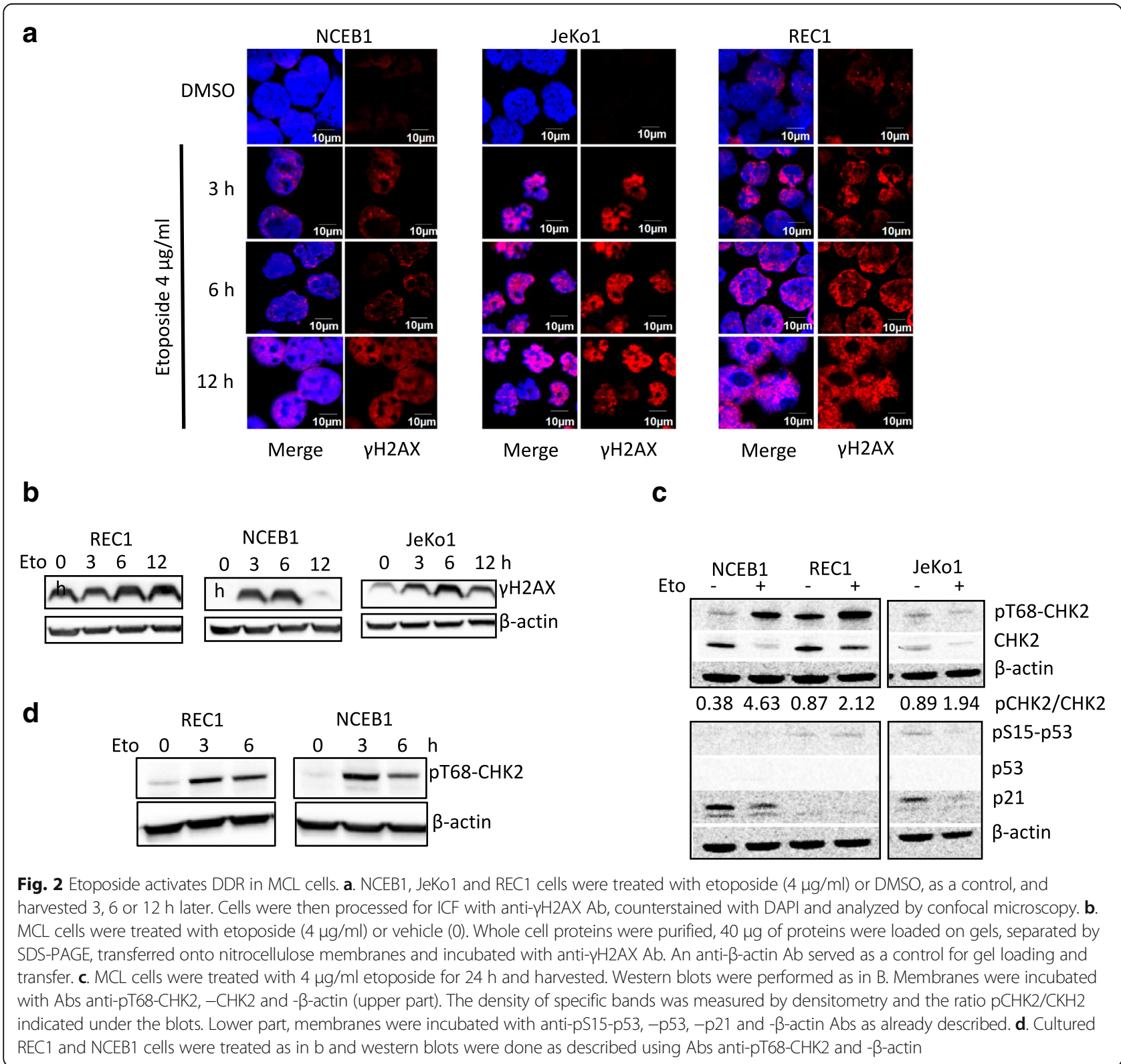




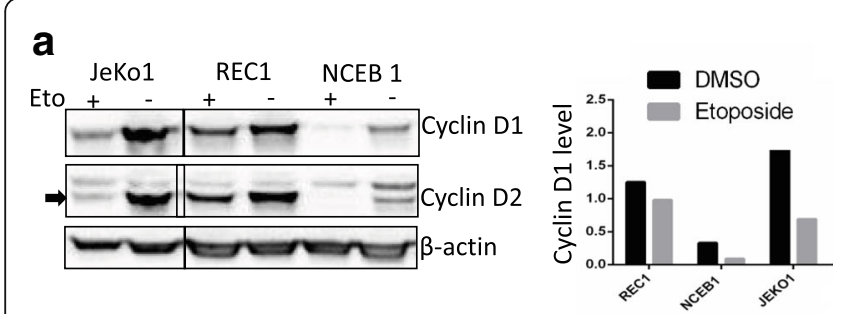

b

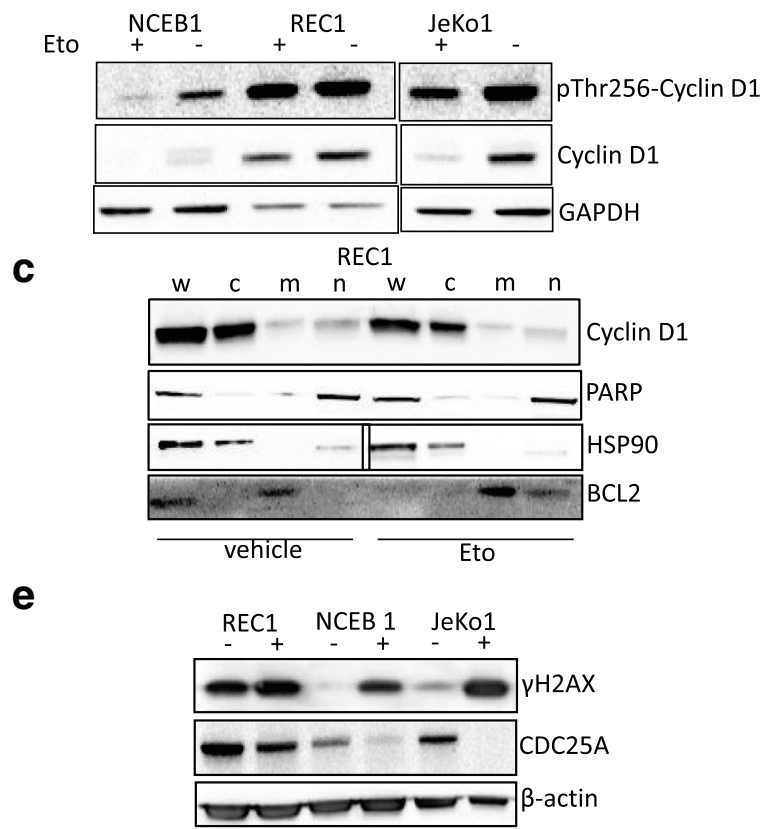

d

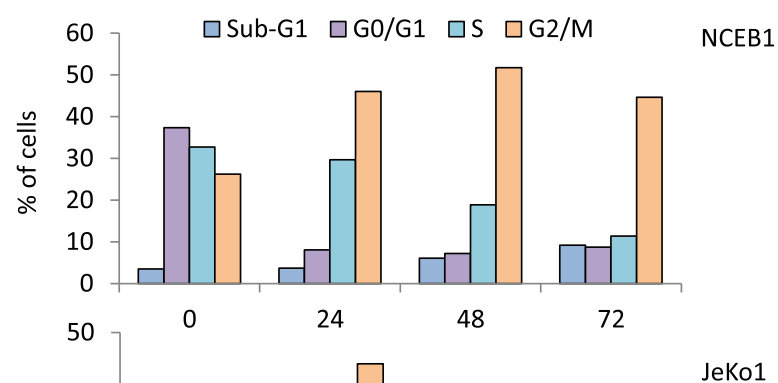

Fig. 3 Cyclin D1 accumulates after genotoxic stress in REC1 cells. a. JeKo1, REC1, NCEB1 cells were treated with $4 \mu \mathrm{g} / \mathrm{ml}$ etoposide for $24 \mathrm{~h}$ or vehicle, as a control, and harvested. Western blots were performed as described in the legend of Fig. 2 using Abs anti-cyclin D1, -cyclin D2 and - $\beta$-actin Abs. The anti-cyclin D2 Ab detects also cyclin D1, the specific cyclin D2 band is arrowed on the figure. The level of cyclin D1 in vehicle and etoposide conditions was estimated by densitometry and reported on the graph. $\mathbf{b}$. Cells were cultured and treated as before and analyzed by western blot with the indicated Abs. Anti-GAPDH Ab served as a control for gel loading and transfer. c. REC 1 cells were treated with $4 \mu \mathrm{g} / \mathrm{ml}$ etoposide for $24 \mathrm{~h}$ or vehicle, as a control, and harvested. We purified proteins either from whole cell extracts (w), or from cytoplasm (c), membranes (m) and nucleus ( $\mathrm{n}$ ) compartments. After SDS-PAGE separation and membrane transfer, blots were incubated with an anti-cyclin D1 Ab. The purity of each fraction was verified with Abs specific for cytosolic protein (HSP90), membrane protein (BCL2) and nuclear protein (PARP). d. NCEB1, JeKo1 and REC1 cells were treated with vehicle (0) or $4 \mu \mathrm{g} / \mathrm{ml}$ etoposide for $24-72 \mathrm{~h}$. The cells were stained with PI and analyzed by FACS (Gallios, Beckman Coulter). Data were processed with the Kaluza software (Beckman Coulter). The percentage of cells within each phase of the cell cycle (sub-G1, G0/G1, S and G2/M) is indicated on the histogram. At least, $10^{4}$ events were gated for each cell for each culture condition. The experiment has been carried out twice. e. MCL cells were treated with vehicle (-) or $4 \mu \mathrm{g} / \mathrm{ml}$ etoposide for $24 \mathrm{~h}(+)$ and harvested. Western blots were done as before with the indicated Abs

\section{Apoptotic response after genotoxic stress necessitates the downregulation of cyclin D1 and a block at the G2/M checkpoint}

Accumulation of cyclin D1 is associated with genomic instability trough relicensing of DNA replication origins, DNA re-replication, DSB checkpoint activation $[22,23]$. We next analyzed cyclin D1 expression in MCL cell lines treated with $4 \mu \mathrm{g} / \mathrm{ml}$ etoposide for $24 \mathrm{~h}$. We observed a dramatic decrease of cyclin D1 level in JeKo1 and NCEB1 not in REC1 cells (Fig. 3a, upper part). This result was confirmed by densitometry (Fig. 3a, lower part). The downregulation of cyclin D1 was not accompanied by a compensatory upregulation of cyclin D2 (Fig. 3a). To be degraded by the proteasome/ubiquitin pathway, cyclin D1 needs to be phosphorylated (p-) on threonine 286 residue [24]. We then analyzed the phosphorylation status of cyclin D1 in etoposide- $(4 \mu \mathrm{g} / \mathrm{ml}$ for $24 \mathrm{~h})$ and vehicle-treated cells. As expected, phosphorylated forms of cyclin D1 were present in MCL cells including REC1 cells; p-cyclin D1 was downregulated as cyclin D1 in NCEB1 and JeKo1 cells following genotoxic insult not in REC1 cells (Fig. 3b). The absence of cyclin D1 degradation does not rely on a default of 
phosphorylation nor nuclear export. In REC1 cells, cyclin D1 resided in the cytosolic portion, mitochondrial membranes and nucleus as we reported previously for mature B cells [25]. Cyclin D1 shuttled into the cytosol after generation of DSBs for degradation by the ubiquitin/proteasome system (UPS). After etoposide treatment, we observed no accumulation of cyclin D1 into the nucleus, indicating that nuclear export occurred in REC1 cells ruling out abnormalities of the XPO1 gene and/or the exportin 1 (Fig. 3c and Additional file 3: Figure S2A). We can speculate that, such as MCL1, cyclin D1 degradation could be mandatory for MCL cells to enter apoptosis and/or senescence. To confirm this point, we used doxorubicin in experimental conditions in which DSBs were generated without triggering apoptosis. Doxorubicin-treated MCL cells (25 nM for $24 \mathrm{~h}$ ) exhibited activation of DDR (Additional file 3: Figure S2B). Moreover, MCL1, CDC25A, and cyclin D1 proteins were not degraded and, in turn, cells did not undergo apoptosis (Additional file 3: Figure S2B and not shown).

Cyclin D1 governs the cell cycle through the G1-S checkpoint. We analyzed the effects of etoposide treatment $(4 \mu \mathrm{g} / \mathrm{ml}$ for $24-72 \mathrm{~h}$ ) on cell cycle distribution after PI staining and flow cytometry analysis. As soon as $24 \mathrm{~h}$ post-treatment, NCEB1 cells were blocked at the G2 phase of the cell cycle and JeKo1 cells at both S and G2 phases (Fig. 3d). This block in the cycle progression was followed by the appearance at 48 and $72 \mathrm{~h}$ posttreatment of apoptotic cells (i.e cells with a sub-G1 DNA content) according to the magnitude of apoptosis. This cell cycle arrest did not occur in REC1 cells (Fig. 3d). Following genotoxic stress, REC1 cells escaped the G2/M block which precedes apoptosis.

CDC25A phosphatase is an essential regulator of $\mathrm{G} 2 / \mathrm{M}$ transition and its degradation in response to DNA damage is critical for cell cycle arrest [26]. After activation of ATM/ ATR and phosphorylation of CHK1/2, CDC25A became hyperphosphorylated and thus, degraded through its ubiquitylation. We next analyzed the level of CDC25A in etoposide- $(4 \mu \mathrm{g} / \mathrm{ml}$ for $24 \mathrm{~h})$ and vehicle-treated cells. CDC25A was not degraded in response to DNA damage in REC1 cells although the protein disappeared almost totally in NCEB1 and JeKo1 cells (Fig. 3e). In agreement with these results the level of CDC25A was maintained both in JeKo1 and REC1 cells following doxorubicin treatment (Additional file 3: Figure S2B).

\section{Cell response after DNA damage depends on the proteasome-ubiquitin pathway}

Collectively, our data suggested that REC1 cells were resistant to etoposide because three main actors of apoptosis, senescence and cell proliferation: cyclin D1, MCL1 and CDC25A failed to be degraded by the proteasome machinery. We verified that the inhibition of proteasome by the MG132 inhibitor allowed cyclin D1, CDC25A, and MCL1 to resist degradation in JeKo1 and NCEB1 cells (Fig. 4a). Furthermore, in JeKo1 cells, a MG132-treatment relieved cell cycle block at the S/G2 transition (Fig. 4b). Cyclin D1, MCL1 and CDC25A are all proteins with a short half-life that are targeted by SCF complexes. Looking for an E3 ubiquitin ligase that could be involved in the ubiquitylation of cyclin D1, MCL1 and CDC25A, we found BTrCP a good candidate. Indeed, if essentially four F-box proteins were shown to contribute to cyclin D1 degradation (FBXO4, FBXW8, SKP2 and FBXO31), $\beta$ TrCP could allow for cyclin D1 ubiquitylation in some conditions [27] and through an unconventional recognition site, ${ }^{279} \mathrm{EEVDLACpT}^{286}$ [28]. Moreover, $\beta$ TrCP targets MCL1 for ubiquitylation and destruction $[29,30]$, and controls the degradation pathway of CDC25A following DNA damage [31]. CReP (constitutive reverter of eIF2 $\alpha$ phosphorylation) is a protein phosphatase 1 (PP1) that targets the translation initiation factor eIF2 $\alpha$ to promote the removal of stress-induced inhibitory phosphorylation and increase cap-dependent translation. CReP is targeted by $\beta$ TrCP for degradation upon DNA damage [32]. In good agreement with our previous results, following etoposide treatment $(4 \mu \mathrm{g} / \mathrm{ml}$ for $24 \mathrm{~h}$ ), the phosphorylated form of eIF2 $\alpha$ was degraded in JeKo1 cells over time but not in REC1 cells (Fig. 4c).

\section{The response of MCL cells to etoposide is not driven by the $\beta \operatorname{TrCP} E 3$ ligase}

Humans have two $\beta \operatorname{TrCP}$ paralogs: $\beta \operatorname{TrCP} 1$ (also known as FBXW1 or BTRC) and $\beta$ TrCP2 (also known as FBXW11) with indistinguishable biochemical properties. Indeed, they share $86 \%$ identical amino acids in the F-box responsible for substrate specificity [33]. The two proteins are encoded by distinct genes localized on 10q24.32 for BTRC and $5 \mathrm{q} 35.1$ for $F B X W 11[15,34]$. The expression of BTRC and FBXW11 mRNAs was studied by a semi-quantitative RTPCR in our panel of MCL cell lines (Granta519, JeKo1, JVM2, Mino, NCEB1, REC1 and Z138 cells; Additional file 2: Table S5). The $F B X W 11$ gene was expressed at a basal low level; by contrast, BTRC gene was expressed in all tested cells although with various levels (data not shown). Some commercially available antibodies against $\beta \mathrm{TrCP}$ detect unrelated proteins in western blots [35]. However, we validated an antibody directed against the $\beta \mathrm{TrCP} 1$ protein using Granta519 and MINO cells transiently transfected with pcDNA3-Flag- $\beta \operatorname{TrCP} 1$ and -2 expression plasmids ([26], data not shown). Two forms of $\beta \mathrm{TrCP} 1$ were detected in JeKo1, NCEB1 and REC1 cells. Etoposide treatment had no effects on $\beta$ TrCP1 level in MCL cells (Fig. $4 d)$. Moreover, the analysis of $\beta \operatorname{TrCP} 1$ level in the panel of MCL cells revealed a heterogeneous expression with no correlation with the magnitude of response towards etoposide (Fig. 4e). These data suggested that $\beta \operatorname{TrCP}$ was not altered in REC1 cells and not involved in cells resistance. 
a
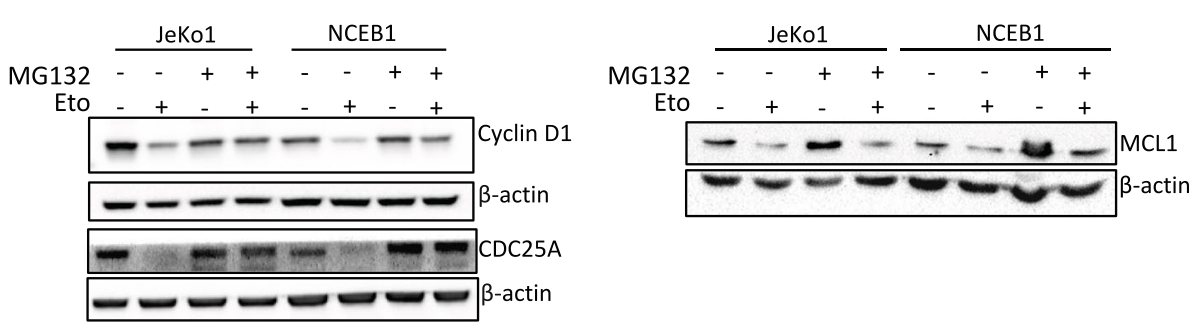

b

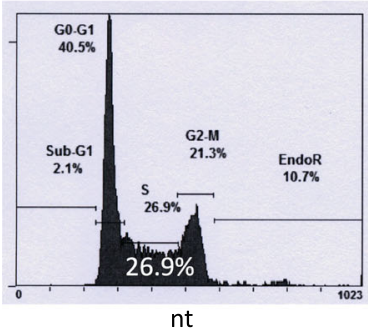

$\mathrm{nt}$

C
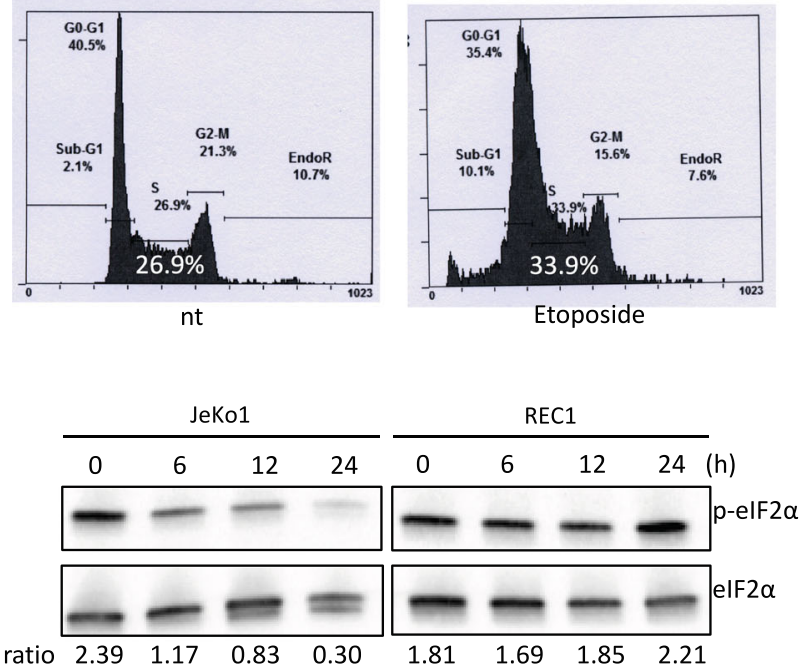

Etoposide
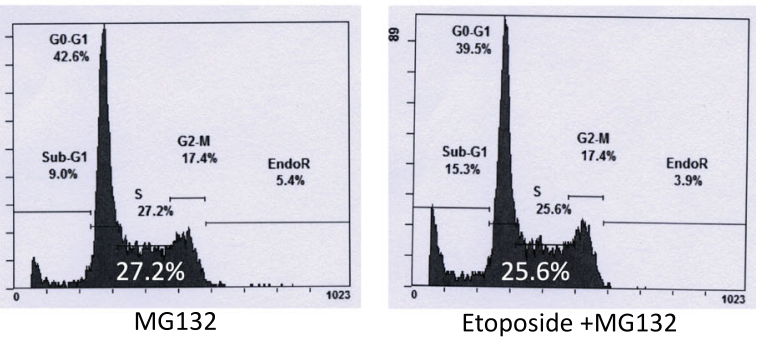

d

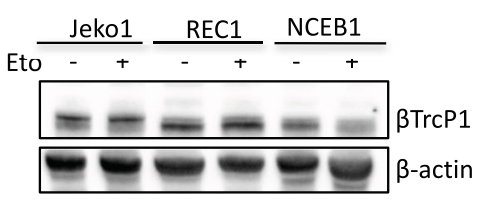

e

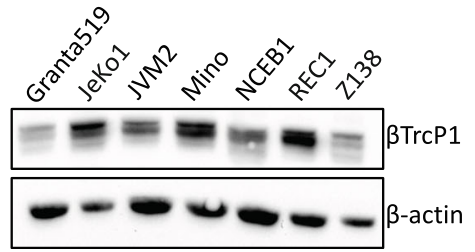

Fig. 4 Cell response depends on the proteasome-ubiquitin pathway. a. JeKo1 and NCEB1 cells were treated with $1 \mu \mathrm{M}$ etoposide, or $5 \mu \mathrm{M}$ MG132, or both for $24 \mathrm{~h}$, or vehicle, as a control, and harvested. Western blots were performed with the indicated Abs as described in the legend of Fig. 2. b. Cells were treated as in a, stained with PI and analyzed by flow cytometry. Cytometry profiles from a representative experiment are shown, the percentage of cells in the S phase is indicated on the graph. c. JeKo1 and REC1 cells were treated with $4 \mu \mathrm{g} / \mathrm{ml}$ etoposide (or vehicle, $0)$ for the indicated periods $(6-24 \mathrm{~h}$ ). Whole cell proteins were purified and analyzed by western blotting with the indicated Abs. The ratio p-elF2a/ elF2a estimated by densitometry, is indicated under the blots. d. Cells were treated with vehicle (-) or etoposide $4 \mu \mathrm{g} / \mathrm{ml}(+)$ for $24 \mathrm{~h}$, then harvested. Whole cell proteins were purified, separated by SDS-PAGE, transferred onto nitrocellulose membranes and immunoblotted with an antibody against $\beta \operatorname{TrCP} 1$ protein. e. Proteins were purified from the indicated MCL cell lines and analyzed by western blot as described in $d$

\section{$26 \mathrm{~S}$ proteasome activity is lowered in REC1 cells}

The $26 \mathrm{~S}$ proteasome is a macromolecular machinery composed of the $20 \mathrm{~S}$ catalytic core and the $19 \mathrm{~S}$ regulator [36]. The $20 \mathrm{~S}$ core complex is shaped as a cylinder formed by a stack of four rings, each ring consisting in seven distinct subunits. The two outer rings are made of the $\alpha$ subunits $(\alpha 1-\alpha 7)$; they mediate the interaction with the 19S regulatory core. The two inner rings are made of the $\beta$ subunits $(\beta 1-\beta 7)$; they possess at least three distinct proteolytic activities that can be monitored using specific fluorogenic substrates: Suc-LLVY-AMC, Z-ARR-AMC, and Z-LLE$A M C$, respectively. $\beta 1, \beta 2$ and $\beta 5$ subunits are referred to as having caspase-, trypsin-, and chymotrypsin-like activities based on their preference for cleaving peptides [36]. We further analyzed the $20 \mathrm{~S}$ proteasome activity in cell lysates from either non-treated JeKo1 and REC1 cells or following a treatment with various proteasome inhibitors. In all cell extracts, chymotrypsin-, trypsin-, and caspaselike activities increased over time to reach a plateau at $60 \mathrm{~min}$ (data not shown). Therefore, we compared cells in various culture conditions at that time. As presented in Fig. 5 (left and right histograms), chymotrypsin and caspase-like activities were similar for JeKo1 and REC1 cells and inhibited by a MG-132 treatment. In agreement with our data, MG-132 binds with a high affinity the $\beta 5$ site and a lower activity the $\beta 1$ site of the proteasome [36]. In sharp contrast, the trypsin-like activity of the $\beta 2$ site in REC1 cells was reduced compared to JeKo1 cells $(p=0.00083229$ with the $t$-test). Whatever the initial activity, it was reduced to the same extent after bortezomib or leupeptin treatments (Fig. 5, middle panel). Bortezomib and leupeptin are both inhibitors of the trypsin-like 

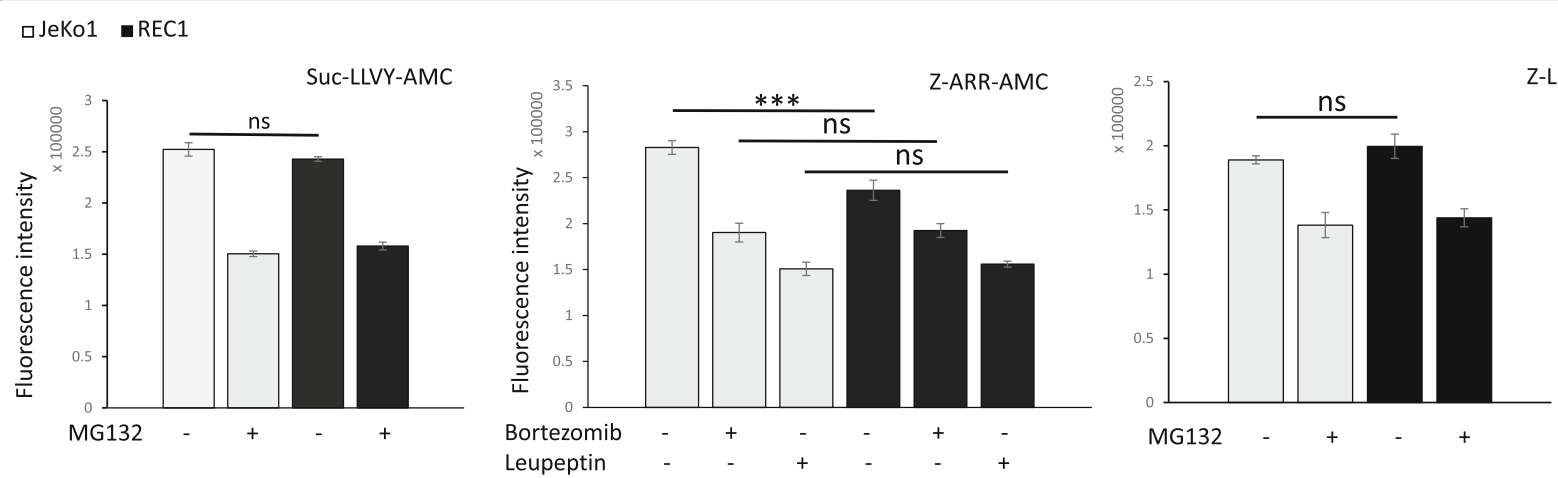

Fig. 5 Proteasome activity is lowered in REC1 cells. JeKo1 and REC1 cells were treated with MG-132 (500 nM), bortezomib (5 nM), or leupeptin $(20 \mu \mathrm{M})$ for $4 \mathrm{~h}$ or vehicle, and protein extracts were prepared. Chymotrypsin-, trypsin- and caspase-like activities were monitored using Suc-LLVYAMC, Z-ARR-AMC, and Z-LLE-AMC fluorogenic substrates, respectively with a reader plate (Victor X4, Perkin Elmer). For all culture conditions and substrates, the protease activity reached a plateau at $60 \mathrm{~min}$. Fluorescence intensities (in arbitrary unit) were taken at that time and presented in the histograms. The experiments were done three times with triplicate samples. ${ }^{* *}, p<0.001$ with the $t$-test

activity [36]. These results showed that the trypsinlike activity of the $20 \mathrm{~S}$ core particle is lowered in REC1 cells compared to JeKo1 cells.

\section{Discussion}

Although therapeutic strategies for MCL have evolved these last years, the disease remains largely incurable. MCL patients develop de novo resistance or acquire resistance to frontline drugs [37]. There is a great need to overcome resistance in MCL patients and to improve their clinical outcome. This can be achieved through a better knowledge of the mechanisms of resistance. We studied the response of a panel of MCL cell lines to genotoxic stress and observed a heterogeneous response. REC1 cells are the most resistant and JeKo1 cells the most sensitive to etoposide, a Top 2 inhibitor that generates DSBs. We observed that three main actors of cell cycle arrest, senescence and apoptosis, namely cyclin D1, MCL1 and CDC25A that are enrolled after a genotoxic stress, fail to be degraded in response to etoposide. We finally provided evidence for a lowered $26 \mathrm{~S}$ proteasome activity that could sustain the accumulation of these proteins and in turn, the resistance of MCL cells.

Defective proteolysis have been reported in MCL cells. Indeed, mutations of $C C N D 1$ gene at the $\mathrm{N}$-terminus increases cyclin D1 protein stability through the attenuation of threonine 286 phosphorylation and its nuclear retention [38]. The phosphorylation of cyclin D1 is mandatory for protein degradation by the UPS. We have shown that cyclin D1 is correctly phosphorylated in resistant REC1 cells after etoposide treatment and exported to the cytoplasmic compartment. Although E36K, Y44D, and C47S CCND1 mutations have not been reported for REC1 cells, we can rule out such a mechanism of resistance. Importantly, in MCL cell lines, CCND1 mutations promote resistance to ibrutinib, an inhibitor of the Bruton tyrosine kinase (BTK) involved in the B-cell receptor (BCR) signaling pathway. Recent studies have provided some clues about ibrutinib resistance including activation of the NF-kB, ERK $1 / 2$ and AKT, alteration of the BCR signaling pathways [39-41]. These studies suggest that multiple mechanisms contribute to ibrutinib resistance. Moreover, a same mechanism, i.e. the accumulation of nuclear cyclin D1, contributes to resistance to several drugs: ibrutinib [38], lenalidomide [12], and etoposide (the present study), drugs that target different pathways. According to these data, an increased stability of cyclin D1 is a major mechanism for MCL cells resistance.

REC1 cells are resistant to proteasome inhibitors: bortezomib (Additional file 3: Figure S2C, upper panel), MG132, and carfilzomib (data not shown)). However, REC1 cells enter apoptosis when treated with KNK-437, an inhibitor of heat-shock factor 1 (HSF1). HSF1 is the master transcription factor for heat shock proteins (HSPs) encoding genes. The inhibition of HSF1 downregulates simultaneously the transcription of HSPB1 and HSPA4 coding for HSP27 and HSP70, respectively. Acosta-Alvear and colleagues reported recently that proteostasis factors such as chaperones and HSPs controlled the response to proteasome inhibitors [42]. In particular, the knockdown of HSF1 sensitizes cells to carfilzomib in agreement with our observation. Moreover, the fact that REC1 cells respond to a HSF1 inhibitor suggests that the UPS although downregulated can be rearmed. Moreover, combining HSP inhibitors and proteasome inhibitors could be efficient therapies for MCL patients resistant to bortezomib/carfilzomib. Clinical trials have demonstrated such efficacy for bortezomib associated with several types of HSP90 [43-45] or HSF1 [46-48] inhibitors for multiple myeloma (MM) patients.

REC1 cells are sensitive to sn38, the metabolically active form of irinotecan, an inhibitor of Top 1, (Additional file 3: Figure S2C, lower panel). Importantly, the $\mathrm{IC}_{50}$ for sn38 is similar for REC1 and NCEB1 and smaller than JeKo1 
cells. sn38 selectively targets Top 1-DNA cleavage complexes which form at the vicinity of replication and transcription complexes to unwind DNA. The stabilization of Top 1-DNA cleavage complexes leads to DNA damage at the time of DNA replication or transcription, and finally to DSBs [49]. DSBs either generated by sn38 or etoposide elicit the same DNA repair response. We showed in this study that DDR was activated in REC1 cells but that DNA repair mechanisms were deficient. This data is confirmed by the triggering of apoptosis after sn38-treatment in REC1 cells, in which the apoptotic machinery is fully functional. There is no cross-resistance in REC1 cells to Top 1 and Top 2 inhibitors. Moreover, the sensitivity/resistance pattern of MCL tumor cells towards drugs is multifactorial and largely dependent on the cell context.

Two studies reported recently a paradoxical resistance of multiple myeloma tumor cells to proteasome inhibitors by decreased levels of $19 \mathrm{~S}$ proteasome regulatory subunits $[42,50]$. These are ATPase subunits as well as nonATPase subunits and seem specific for a cell line. A downregulation of $19 \mathrm{~S}$ sub-units could sustain the global decreased proteasome activity observed in REC1 cells and could be key determinant of resistance to proteasome inhibitors and other drugs in MCL tumor cells. However, the demonstration that the reduced trypsin-like activity bore by the $20 \mathrm{~S}$ core complex and, in particular, the $\beta 2$ subunit (or PSMB7), highlights another type of proteasome subunit abnormality. To our knowledge, this is the first report of a putative role of the $\beta 2$ subunit in a resistance process. In contrast, the involvement of the $\beta 5$ subunit in the resistance of various hemopathies is well described. For example, in a myelomonocytic THP1 cell line, selected for acquired resistance to bortezomib, the PSMB5 gene coding for PSMB5, the $\beta 5$ subunit, is mutated and the corresponding protein overexpressed [51]. In MM tumor cells resistant to bortezomib, no such mutations were found [52], rather a constitutive activation of the STAT3 signaling pathway and in turn, the upregulation of the $\beta 5$ subunit [53]. However, the PSMB7 gene coding for $\beta 2$ subunit is overexpressed in a large variety of solid cancers and myeloid leukemias [54]. A survey of public available data bases (COSMIC, canSAR, Cancer Cell Line Ecyclopedia) indicated that PSMB5 and PSMB7 genes are not mutated, deleted nor amplified in REC1 cells. Further experiments should address these points.

Cancer stem cells (CSCs) or cancer-initiating cells (CICs) belong to a population of self-renewing cells that sustain the long-term clonal maintenance of the tumor [55]. Strong evidences support a link between stemness and resistance to drugs. CSCs/CICs have develop plethora of strategies to resist anticancer therapies including elevated activity for DNA damage detection and repair, increased ability for xenobiotic efflux, unbalance between the anti- vs. pro-apoptotic mechanisms, reduced production of free radicals etc. Interestingly, a low proteasome activity has been reported as a marker for breast cancer and head and neck CSCs/CICs $[56,57]$.

Several recurrent somatic mutations are described in tumor cells of MCL patients [58]. Among them, mutations of ATM, CCND1, TP53, MLL2, TRAF2 and NOTCH1 genes are frequently encountered and account for resistance to drugs. Most of them target the BCR and NF- $\mathrm{kB}$ signaling pathways and define actionable gene targets. However, deletion of FBXO25 [9], mutation of UBR5 [10] or, as suggested here, a decreased of global $26 \mathrm{~S}$ proteasome activity modify the UPS and in turn, the sensitivity to drugs and the clinical response of MCL patients. Since, the resistance to proteasome inhibitor and/or other drugs is convoyed by defaults of UPS, the restoration of its activity seems determinant to bypass resistance and to achieve a full response towards treatments.

\section{Conclusions}

MCL patients are either resistant or develop resistance after the treatments with frontline agents. Several mechanisms of resistance have been described in MCL tumor cells that escape apoptosis. We report here that a lowered 29S proteasome activity could be another mechanism of MCL cell resistance. Developing a strategy to counteract this mechanism of resistance may have significant therapeutic value.

\section{Additional files}

Additional file 1: Figure S1. MCL cell lines were treated with vehicle or etoposide $\left(10^{-3}-10^{2} \mu \mathrm{g} / \mathrm{ml}\right)$ for $24-72 \mathrm{~h}$. Cell viability was assayed using an MTS assay (CellTiter $96^{\circledR} \mathrm{AQ}$ ueous One Solution Cell Proliferation Assay, Promega). The absorbance (OD at $490 \mathrm{nM}$ ) of each clone treated with the drug is expressed relative to that of the corresponding clone treated with vehicle (defined as 100\%). For each set of culture conditions, the mean \pm SD of triplicate ratios is indicated on the curves. The experiment was performed twice. The results were analyzed with the PRISM ${ }^{\oplus} 6$ software and reported in the Tables S1 and S2 in Additional file 1. (PDF 168 kb)

Additional file 2: Table S1. Calculation of $\mathrm{IC}_{50}$ for etoposide-treated $\mathrm{MCL}$ cell lines. Table S2. Calculation of AUC for etoposide-treated MCL cell lines. Table S3. MCL1 level is variously regulated following etoposide treatment. Table S4. Genetic characteristics of MCL cell lines. Table S5. Sequences of the primers used for RT-PCR. Additional references. (DOCX $120 \mathrm{~kb}$ )

Additional file 3: Figure S2. A. REC1 cells were treated with vehicle or etoposide $4 \mu \mathrm{g} / \mathrm{ml}$ for $2-24 \mathrm{~h}$ and harvested. Cells ( $10^{5}$ cells per spot) were cytospun on Superfrost glass slides, at $500 \mathrm{~g}$ for $3 \mathrm{~min}$, then fixed in $4 \%$ paraformaldehyde (PFA) and permeabilized by incubation with $0.5 \%$ Triton-X100 ( $/ / \mathrm{v})$ for $5 \mathrm{~min}$. Slides were then stained with rabbit anticyclin D1 primary Ab (sc-718, Santa Cruz Biotech.) and AlexaFuor ${ }^{\circledR} 546$ goat anti-rabbit IgG (Life Technologies) secondary Ab. DAPI (4',6-diamidino-2-phenylindole dihydrochloride, Molecular Probes) served for nuclei counterstaining. Slides were mounted, and analyzed with a Fluoview FV 1000 confocal microscope and Fluoview Viewer software (Olympus). B. Cultured JeKo1 and REC1 cells were treated with vehicle (Ctrl) or doxorubicine (Dox $25 \mathrm{nM}$ ) for $24 \mathrm{~h}$. Whole cell proteins were purified, separated by SDS-PAGE, and immunoblotted with the indicated antibodies. An anti- 
$\beta$-actin served as a control of charge and transfer. C. Cultured JeKo1 and REC1 cells were treated with vehicle (Ctrl) or bortezomib $\left(10^{-1}-10^{4} \mathrm{nM}\right)$ or sn38 $\left(10^{-1}-10^{3} \mathrm{nM}\right)$ for $24 \mathrm{~h}$ and then cell viability assessed by a MTS assay as described in the legend of the Fig. 1a. Dose-reponse curves were drawn with the PRISM ${ }^{\circledR}$ software (GraphPad, La Jolla, CA) and the $\mathrm{IC}_{50}$ were deduced from the data. (PPTX $5260 \mathrm{~kb}$ )

\section{Abbreviations}

Ab: antibody; ampl: amplified; ATM: ataxia telangectasia mutant; ATR: ATM and Rad3-related; BCL2: B-cell lymphoma 2; BCR: B-cell receptor; BTK: Bruton tyrosine kinase; $C_{12} F D G$ : 5-dodecanoylaminofluorescein di- $\beta$-D-galactopyranoside; CDC25A: cell division cycle 25 homolog A; CDNA: complementary DNA; CHK1/ 2: checkpoint kinase 1/2; CIC: Cancer-initiating cell; CReP: constitutive reverter of elF2a phosphorylation; CSC: cancer stem cell; DDR: DNA damage response; del: deleted; DSB: double-strand break; elF2a: eukaryotic translation initiation factor 2a; hom: homozygous; HR: homologous recombination; HSP: heat shock protein; ICF: immunocytofluorescence; MCL: mantle cell lymphoma; MCL1: myeloid cell leukaemia sequence 1; MM: multiple myeloma; MTS: (3-(4,5-dimethylthiazol-2-yl)5-(3-carboxymethoxyphenyl)-2-(4-sulfophenyl)-2H-tetrazolium); mut: mutated; nd: not determined; NHEJ: non-homologous end-joining; p-: phosphorylated; PI: propidium iodide; PP1: protein phosphatase 1; GRT-PCR: quantitative reversetranscriptase polymerase chain reaction; QVD-OPH: broad spectrum caspase inhibitor; SCF: SKP1/Cullin/F-box protein containing complex; SDS-PAGE: sodium dodecyl sulphate polyacrylamide gel electrophoresis; Top: topoisomerase; upd: uniparental disomy; UPS: ubiquitin proteasome system; wt: wild-type; $\beta \operatorname{TrCP}: \beta$-transducin repeat containing protein

\section{Acknowledgements}

We thank Anne Barbaras for technical assistance, Daniele Guardavaccaro (Hubrecht Institute, Utrecht, The Netherlands) for the gift of $\beta \operatorname{TrCP} 1 / 2$ expression plasmids, and Olivier Coqueret (Centre de Recherche en Cancérologie, Angers, France) for the gift of sn38. We are grateful to Véronique Baldin (Centre de Recherche en Biologie Moléculaire, Montpellier, France), Sébastien Léon (Université Paris Diderot, Institut Jacques Monod, Paris, France), Manuel Rodriguez (Institut des Technologies Avancées en Sciences du Vivant, CNRS USR3505, Toulouse, France), Chann Lagadec (Université de Lille 1, INSERM U908, Lille, France) and Hervé Mittre (Laboratoire de génétique, Centre Hospitalo-Universitaire, Caen, France) for helpful discussions, and Gaël Roué (IDIBAPS, Barcelona, Spain) and Arthur Vincent-Coves for reading the manuscript.

\section{Funding}

This project has been financially supported in part by the Ligue contre le Cancer (Comité du Calvados) to BS. The Ligue contre le Cancer had no role in the design of the study and collection, analysis, and interpretation of data or in writing the manuscript. KBY received study grants awarded by the Ministry of Higher Education and Scientific Research of Tunisia.

\section{Availability of data and materials}

All data generated or analyzed during this study are included in this published article and its supplementary information files.

\section{Authors' contributions}

$\mathrm{KBY}, \mathrm{SB}, \mathrm{EC}, \mathrm{HM}, \mathrm{CC}, \mathrm{PJV}$, FJ contributed to data acquisition, analysis, and interpretation; FBF supervised the study; BS designed the study, interpreted the data, supervised the study and wrote the paper. The authors read, revised and approved the final manuscript.

\section{Ethics approval and consent to participate}

Not applicable

\section{Consent for publication}

Not applicable

\section{Competing interests}

The authors declare that they have no competing interests.

\section{Publisher's Note}

Springer Nature remains neutral with regard to jurisdictional claims in published maps and institutional affiliations.

\section{Author details}

Normandie Univ, INSERM UMR 1245, UNIROUEN, UNICAEN, Caen, France. ${ }^{2}$ Faculté de médecine, Laboratoire de Génétique, $d^{\prime}$ Immunologie et de Pathologie humaines, Université de Tunis El Manar, Tunis, Tunisia. ${ }^{3}$ Département d'Hématologie Clinique, Centre de Lutte contre le Cancer Henri Becquerel, Rouen, France. ${ }^{4} \mathrm{MICAH}$, UFR Santé, CHU Côte de Nacre, 14032 Caen Cedex, France.

Received: 9 January 2017 Accepted: 3 August 2017

Published online: 10 August 2017

\section{References}

1. Jares P, Colomer D, Campo E. Genetic and molecular pathogenesis of mantle cell lymphoma. Perspectives for new targeted therapeutics. Nat Rev Cancer. 2007:7:750-62.

2. Jares P, Colomer D, Campo E. Molecular pathogenesis of mantle cell lymphoma. J Clin Invest. 2012;122:3416-23.

3. Yu W, Denu RA, Krautkramer KA, Grindle KM, Yang DT, Asimakopoulos F, et al. Loss of SIRT3 provides growth advantage for B cell malignancies. J Biol Chem. 2016:291:3268-79.

4. Jackson SP, Bartek J. The DNA-damage response in human biology and disease. Nature. 2009:461:1071-8.

5. Beà S, Valdés-Mas E, Navarro A, Salaverria I, Martín-Garcia D, Jares P, et al. Mutation and genomic deletion status of ataxia telangiectasia mutated (ATM) and p53 confer specific gene expression profiles in mantle cell lymphoma. Proc Natl Acad Sci U S A. 2013;110:18250-5.

6. Greiner TC, Dasgupta C, Ho W, Weisenburger DD, Smith LM, Lynch JC, et al. Mutation and genomic deletion status of ataxia telangiectasia mutated (ATM) and p53 confer specific gene expression profiles in mantle cell lymphoma. Proc Natl Acad Sci U S A. 2006;103:2352-7.

7. Pérez-Galán P, Dreyling M, Wiestner A. Mantle cell lymphoma. Biology, pathogenesis, and the molecular basis of treatment in the genomic era. Blood. 2011;117:26-38.

8. Chen R, Sanchez J, Rosen ST. Clinical management updates in mantle cell Jymphoma. Oncology. 2016;30:353-60.

9. Baumann U, Fernández-Sáiz V, Rudelius M, Lemeer S, Rad R, Knorn AM, et al. Disruption of the PRKCD-FBXO25-HAX-1 axis attenuates the apoptotic response and drives lymphomagenesis. Nat Med. 2014;20:1401-9.

10. Meissner B, Kridel R, Lim RS, Rogic S, Tse K, Scott DW, et al. The E3 ubiquitin ligase UBR5 is recurrently mutated in mantle cell lymphoma. Blood. 2013; 121:3161-4.

11. Jones RJ, Bjorklund CC, Baladandayuthapani V, Kuhn DJ, Orlowski RZ. Drug resistance to inhibitors of the human double minute-2 E3 ligase is mediated by point mutations of p53, but can be overcome with the p53 targeting agent RITA. Mol Cancer Ther. 2012;11:2243-53.

12. Moros A, Bustany S, Cahu J, Saborit-Villarroya I, Martínez A, Colomer D, et al. Antitumoral activity of lenalidomide in in vitro and in vivo models of mantle cell lymphoma involves the destabilization of cyclin D1/p27KIP1 complexes. Clin Cancer Res. 2014;20:393-403.

13. Cahu J, Sola B. A sensitive method to quantify senescent cancer cells. J Vis Exp. 2013; doi:10.3791/50494

14. Vlashi E, Kim K, Lagadec C, Donna LD, McDonald JT, Eghbali M, et al. In vivo imaging, tracking, and targeting of cancer stem cells. J Natl Cancer Inst. 2009;101:350-9.

15. Putters J, Slotman JA, Gerlach JP, Strous GJ. Specificity, location and function of $\beta \operatorname{TrCP}$ isoforms and their splice variants. Cell Signal. 2011;23:641-7.

16. Chen R, Chubb S, Cheng T, Hawtin RE, Gandhi V, Plunkett W. Responses in mantle cell lymphoma cells to SNS-032 depend on the biological context of each cell line. Cancer Res. 2010:70:6587-97.

17. Jekimovs C, Bolderson E, Suraweera A, Adams M, O'Byrne KJ, Richard DJ. Chemotherapeutic compounds targeting the DNA double-strand break repair pathways: the good, the bad, and the promising. Front Oncol. 2014;4:86.

18. Lanigan F, Geraghty JG, Bracken AP. Transcriptional regulation of cellular senescence. Oncogene. 2011;30:2901-11.

19. Mah LJ, El-Osta A, Karagiannis TC. gammaH2AX: a sensitive molecular marker of DNA damage and repair. Leukemia. 2010;24:679-86.

20. Stracker TH. The ATM signaling network in development and disease. Front Genet. 2013:4:37.

21. Williamson CT, Kubota E, Hamill JD, Klimowicz A, Ye R, Muzik H, et al. Enhanced cytotoxicity of PARP inhibition in mantle cell lymphoma harbouring mutations in both ATM and p53. EMBO Mol Med. 2012;4:515-27. 
22. Aggarwal P, Lessie MD, Lin DI, Pontano L, Gladden AB, Nuskey B, et al. Nuclear accumulation of cyclin D1 during $S$ phase inhibits Cul4-dependent Cdt1 proteolysis and triggers p53-dependent DNA rereplication. Genes Dev. 2007:21:2908-22.

23. Vaites LP, Lian Z, Lee EK, Yin B, DeMicco A, Bassing CH, Diehl JA. ATM deficiency augments constitutively nuclear cyclin D1-driven genomic instability and lymphomagenesis. Oncogene. 2013;33:129-33.

24. Alao JP. The regulation of cyclin D1 degradation: roles in cancer development and the potential for therapeutic invention. Mol Cancer. 2007;6:24.

25. Tchakarska G, Roussel M, Troussard X, Sola B. Cyclin D1 inhibits mitochondrial activity in B cells. Cancer Res. 2011;71:1690-9.

26. Busino L, Donzelli M, Chiesa M, Guardavaccaro D, Ganoth D, Dorrello NV, et al. Degradation of Cdc25A by $\beta$-TrCP during $S$ phase and in response to DNA damage. Nature. 2003;426:87-91.

27. Kanie T, Onoyama I, Matsumoto A, Yamada M, Nakatsumi $H$, Tateishi $Y$, et al. Genetic reevaluation of the role of F-box proteins in cyclin D1 degradation. Mol Cell Biol. 2012:32:590-605.

28. Wei S, Yang HC, Chuang HC, Yang J, Kulp SK, Lu PJ, et al. A novel mechanism by which thiazolidinediones facilitate the proteasomal degradation of cyclin D1 in cancer cells. J Biol Chem. 2008;283:26759-70.

29. Inuzuka H, Shaik S, Onoyama I, Gao D, Tseng A, Maser RS, et al. SCF(FBW7) regulates cellular apoptosis by targeting MCL1 for ubiquitylation and destruction. Nature. 2011:470:104-9.

30. Ren H, Koo J, Guan B, Yue P, Deng X, Chen M, et al. The E3 ubiquitin ligases $\beta-\operatorname{TrCP}$ and FBXW7 cooperatively mediates GSK3-dependent mcl-1 degradation induced by the Akt inhibitor API-1, resulting in apoptosis. Mol Cancer. 2013;12:146

31. Jin J, Ang XL, Ye X, Livingstone M, Harper JW. Differential roles for checkpoint kinases in DNA damage-dependent degradation of the Cdc25A protein phosphatase. J Biol Chem. 2008;283:19322-8.

32. Loveless TB, Topacio BR, Vashisht AA, Galaang S, Ulrich KM, Young BD, et al. DNA damage regulates translation through $\beta$-TRCP targeting of CReP. PLoS Genet. 2015;11:e1005292

33. Winston JT, Koepp DM, Zhu C, Elledge SJ, Harper JW. A family of mammalian F-box proteins. Curr Biol. 1999;9:1180-2.

34. Frescas D, Pagano M. Deregulated proteolysis by the F-box proteins SKP2 and beta-TrCP: tipping the scales of cancer. Nat Rev Cancer. 2008;8:438-49.

35. Thomas Y, Coux O, Baldin V. $\beta \operatorname{TrCP}$-dependent degradation of CDC25B phosphatase at the metaphase-anaphase transition is a pre-requisite for correct mitotic exit. Cell Cycle. 2011:9:4338-50.

36. Grigoreva TA, Tribulovich VG, Garabadzhiu AV, Melino G, Barlev NA. The 265 proteasome is a multifaceted target for anti-cancer therapies. Oncotarget. 2015:6:24733-49.

37. Dreyling M, Ferrero S, on behalf of European Mantle Cell Lymphoma Network. The role of targeted treatment in mantle cell lymphoma: is transplant dead or alive? Haematologica. 2016;101:104-14.

38. Mohanty A, Sandoval N, Das M, Pillai R, Chen L, Chen RW, et al. CCND1 mutations increase protein stability and promote ibrutinib resistance in mantle cell lymphoma. Oncotarget. 2016;7:73558-72.

39. Rahal R, Frick M, Romero R, Korn JM, Kridel R, Chan FC, et al. Pharmacological and genomic profiling identifies NF-KB-targeted treatment strategies for mantle cell lymphoma. Nat Med. 2014;20:87-92.

40. Ma J, Lu P, Guo A, Cheng S, Zong H, Martin P, et al. Characterization of ibrutinib-sensitive and -resistant mantle lymphoma cells. Br J Haematol. 2014;166:849-61

41. Saba NS, Liu D, Herman SE, Underbayev C, Tian X, Behrend D, et al. Pathogenic role of B-cell receptor signaling and canonical NF-KB activation in mantle cell lymphoma. Blood. 2016;128:82-92.

42. Acosta-Alvear D, Cho MY, Wild T, Buchholz TJ, Lerner AG, Simakova O, et al. Paradoxical resistance of multiple myeloma to proteasome inhibitors by decreased levels of 195 proteasomal subunits. elife. 2015;4:e08153.

43. Richardson PG, Chanan-Khan AA, Lonial S, Krishnan AY, Carroll MP, Alsina M, et al. Tanespimycin and bortezomib combination treatment in patients with relapsed or relapsed and refractory multiple myeloma: results of a phase 1/ 2 study. Br J Haematol. 2011;153:729-40.

44. Nakashima T, Ishii T, Tagaya H, Seike T, Nakagawa H, Kanda Y, et al. New molecular and biological mechanism of antitumor activities of KW-2478, a novel nonansamycin heat shock protein 90 inhibitor, in multiple myeloma cells. Clin Cancer Res. 2010;16:2792-802.
45. Ishii T, Seike T, Nakashima T, Juliger S, Maharaj L, Soga S, et al. Anti-tumor activity against multiple myeloma by combination of KW-2478, an Hsp90 inhibitor, with bortezomib. Blood Cancer J. 2012;2:e68.

46. Heimberger $T$, Andrulis M, Riedel S, Stuhmer T, Schraud $H$, Beilhack $A$, et al. The heat shock transcription factor 1 as a potential new therapeutic target in multiple myeloma. Br J Haematol. 2013;160:465-76.

47. Bustany S, Cahu J, Descamps G, Pellat-Deceunynck C, Sola B. Heat shock factor 1 is a potent therapeutic target for enhancing the efficacy of treatments for multiple myeloma with adverse prognosis. J Hematol Oncol. 2015;8:40.

48. Shah SP, Nooka AK, Jaye DL, Bahlis NJ, Lonial S, Boise LH. Bortezomibinduced heat shock response protects multiple myeloma cells and is activated by heat shock factor 1 serine 326 phosphorylation. Oncotarget. 2016, in press. doi: 10.18632/oncotarget.10847.

49. Pommier $Y$. Topoisomerase I inhibitors: camptothecins and beyond. Nat Rev Cancer. 2006:6:789-802.

50. Tsvetkov P, Mendillo ML, Zhao J, Carette JE, Merrill PH, Cikes D, et al. Compromising the 195 proteasome complex protects cells from reduced flux through the proteasome. elife. 2015;4:e08467.

51. Oerlemans R, Franke NE, Assaraf YG, Cloos J, van Zantwijk I, Berkers CR, et al. Molecular basis of bortezomib resistance: proteasome subunit beta5 (PSMB5) gene mutation and overexpression of PSMB5 protein. Blood. 2008; 112:2489-99.

52. Lichter DI, Danaee H, Pickard MD, Tayber O, Sintchak M, Shi H, et al. Sequence analysis of $\beta$-subunit genes of the $20 \mathrm{~S}$ proteasome in patients with relapse multiple myeloma treated with bortezomib or dexamethasone. Blood. 2012;120:4513-6.

53. Vangala JR, Dudem S, Jain N, Kalivendi SV. Regulation of PSMB5 protein and $\beta$ subunits of mammalian proteasome by constitutively activated signal transducer and activator of transcription 3 (STAT3): potential role in bortezomib-mediated anticancer therapy. J Biol Chem. 2014;289:12612-22.

54. Rouette A, Trofimov A, Haberl D, Boucher G, Lavallée VP, D'Angelo G, et al. Expression of immunoproteasome genes is regulated by cell-intrinsic andextrinsic factor in human cancers. Sci Rep. 2016:6:34019.

55. Kreso A, Dick JE. Evolution of the cancer stem cell model. Cancer Stem Cell. 2014;14:275-91.

56. Vlashi E, Lagadec C, Chan M, Frohnen P, McDonald AJ, Pajonk F. Targeted elimination of breast cancer cells with low proteasome activity is sufficient for tumor regression. Breast Cancer Res Treat. 2013;141:197-203.

57. Lagadec C, Vlashi E, Bhuta S, Lai C, Mischel P, Werner M, et al. Tumor cells with low proteasome subunit expression predict overall survival in head and neck cancer patients. BMC Cancer. 2014;14:152.

58. Ahmed M, Zhang L, Nomie K, Lam L, Wang M. Gene mutations and actionable genetic lesions in mantle cell lymphoma. Oncotarget. 2016;7:58638-48.

\section{Submit your next manuscript to BioMed Central and we will help you at every step:}

- We accept pre-submission inquiries

- Our selector tool helps you to find the most relevant journal

- We provide round the clock customer support

- Convenient online submission

- Thorough peer review

- Inclusion in PubMed and all major indexing services

- Maximum visibility for your research

Submit your manuscript at www.biomedcentral.com/submit 